\title{
RESPONSES OF GRAIN AND STRAW YIELDS OF WINTER WHEAT ( $C v$. Tajan) TO LIMITED IRRIGATION IN SEMI-ARID ENVIRONMENT
}

\author{
Abolfazl NASSERI \\ Department of Agricultural Engineering, East Azarbaijan \\ Research Center for Agriculture and Natural Resources, Tabriz, Iran \\ nasseri.ab@gmail.com
}

Received Date : 20.02.2012 Accepted Date : 10.07.2012

\begin{abstract}
This study was conducted to investigate responses of winter wheat (cv. Tajan) production to limited irrigation under semi-arid environment. The study included four treatments comprising irrigation at cumulative Etc=100 $\mathrm{mm}$ (I1), Etc $=$ 100 and $230 \mathrm{~mm}$ (I2), Etc = 100, 230 and $350 \mathrm{~mm}$ (I3) and Etc = 100, 230, 350 and $400 \mathrm{~mm}$ (I4). Results revealed that the applying treatments of I3 and I4 produced similar 1000-grain weight (TGW), harvest index(HI), grain (GY), biological (BY), and straw (SY) yields. Biological yield is evidently affected by grain and straw yields. The findings showed that to obtain optimum production for wheat cv. Tajan in Moghan, Iran climate condition, it is recommended to irrigate this crop four times (I3).
\end{abstract}

Keywords: Winter wheat, Wheat yield, Limited irrigation, Irrigation management

\section{INTRODUCTION}

The cultivation area of wheat (Triticum aestivum L.) in Iran is about 6 million hectares (FAO, 2007). To acquire the potential yield of wheat in the north-west of Iran with average rainfall of $260 \mathrm{~mm}$ (Nasseri, 2009), this crop is irrigated. The studies showed that yield and yield components of wheat depend on the proper irrigation management. For example, Abdmishani and Jafari Shabestari (1986) reported that wheat irrigation prior to sowing, at the stem elongation, flowering and milking stages produced the highest yield. While irrigation only prior to sowing produced the lowest yield and 1000-grain weight (TGW). The authors also stated that the highest 1000-grain weight were obtained from the plots irrigated five times. English and Nakamura (1989) reported that under full irrigation with high frequency, did not increase wheat yield. While irrigation with interval of two weeks produced the highest yield. Oweis (1997) showed that one or two times irrigation at the sensitive stages of wheat to water deficit increased grain yield (GY) as 2 to 5 times. In addition, limited irrigation at growing season especially at the critical stages of wheat reduced yield (Musick and Porter,1990; Mahmood et al., 2002).

Hanks and Sorensen (1984) reported that for reduction of seasonal evapotranspiration until onehalf, for spring wheat under water stress by line source sprinkler, harvest index was not significantly varied. Musick and Porter (1990) reported that the ranges of harvest index of wheat for high-yielding cultivars are from 0.38 to 0.50 . Passioura (1977) concluded that grain filling is the sensitive stage to the limited water that affects harvest index of wheat.

Relationship between crop yield and applied water amount is presented by the water-yield function. This function can be expressed as a second or third order polynomial (Hexem and Heady, 1978). Nasseri and Fallahi ( 2007) investigated water use efficiency
(WUE) of wheat by deficit irrigation and concluded that WUE averaged from 0.6 to $1.9 \mathrm{~kg} \mathrm{~m}^{-3}$. Also, they proposed a multiple - nonlinear regressional model for grain yield as a function of applied water amount, wheat growth stage, and wheat varieties. Nitrogen fertilization enhances water use efficiency (Fallahi et al., 2008). Doorenbos and Kassam (1979) related percent yield reduction to percent evapotranspiration deficit as a production function. Suitable management for irrigation practices of wheat is not well recognized in the north-west of Iran. The objective of the present study was to investigate responses of grain and straw yields, and harvest index of winter wheat ( $c v$. Tajan) to limited irrigation.

\section{MATERIAL AND METHODS}

The field experiments were conducted at the Agricultural Research Center of Moghan, Iran with latitude $39^{\circ} 39^{\prime} \mathrm{N}$, longitude $47^{\circ} 55^{\prime} \mathrm{E}$, and $31.9 \mathrm{~m}$ above mean sea level with a semi-arid climate. The average air temperature during the growing season ranged from $5.4{ }^{\circ} \mathrm{C}$ to $16.6{ }^{\circ} \mathrm{C}$, and cumulative rainfall was $165 \mathrm{~mm}$. The field soil was clay loam with average wilting point (WP), field capacity (FC), and $\mathrm{pH}$ of $22.4 \%, 31.5 \%$ (by weight), and 7.2, respectively.

Winter wheat (Triticum aestivum L.) cv. Tajan was sown on Dec. at seeding rate of $160 \mathrm{~kg} \mathrm{ha}^{-1}$ on six rows with $8 \mathrm{~m}$ long and $20 \mathrm{~cm}$ apart $\left(8 \times 1.2 \mathrm{~m}^{2}\right.$ plots $)$. After seeding, the sown site was uniformly irrigated with $75 \mathrm{~mm}$ of water. The experimental treatments were based on long-duration estimated evapotranspiration of wheat (Etc). Four treatments comprising irrigation at cumulative Etc $=100 \mathrm{~mm}$ (I1), Etc $=100$ and $230 \mathrm{~mm}(\mathrm{I} 2)$, Etc $=100,230$ and 350 $\mathrm{mm}$ (I3) and Etc $=100,230,350$ and $400 \mathrm{~mm}$ (I4) were laid out in completely randomized blocks with three replications. Applications and measurements of irrigation water in plots were done by siphons from 
the ditchs, and by a connected-flow meter to a siphon, respectively. All plots were blocked at their ends. Fertilizer of $\mathrm{N}$ as urea was applied to the soil before 2nd and 3th irrigation events as 100 , and $200 \mathrm{~kg} \mathrm{ha}^{-1}$,

$\mathrm{HI}(\%)=$ Grain yield $\left(\mathrm{kg} \mathrm{ha}^{-1}\right) /$ Biological yield $\left(\mathrm{kg} \mathrm{ha}^{-1}\right)$

respectively. After maturity in the mid-June, the plots were harvested for biological, grain, straw, and 1000grain weights. Harvest index (HI) was calculated by:

\section{RESULTS AND DISCUSSION}

\subsection{0-Grain Weight}

The effect of experimental treatments on 1000grain weight was significant $(\mathrm{p} \leq 0.05$, Table 1$)$. Treatments of I2, I3 and I4 produced similar but I1 $(35.3 \mathrm{~g})$ produced the lowest TGW values (Fig. 1). This finding agrees with the results of Abdmishani and Jafari Shabestari (1986). Applying five events of irrigation (I4) produced the highest 1000-grain weight (Tables 2 and 3 ).

\subsection{Grain Yield}

The effect of irrigation events on grain yield was statistically significant $(\mathrm{p} \leq 0.05$, Table 1$)$. The achieved GY from I1 and I2 were similar (Fig. 1). Also, grain yields from the treatments of I3 and I4 did not vary statistically (Fig. 1). In other words, irrigation with three events did not increase the grain yield relative to the grain yield with two events ( Table 3). It seems that this finding is derived from the effect of experimental treatments on 1000-grain weight. Consequently, irrigation of wheat four times (as I3) is adequate to obtain optimum grain yield of wheat.

\subsection{Biological And Straw Yield}

The effect of irrigation events on biological yield was also significant (Table 1). Applying I1, and I4 produced the lowest $\left(5800 \mathrm{~kg} \mathrm{ha}^{-1}\right)$, and the highest (7058 $\mathrm{kg} \mathrm{ha}^{-1}$ ) straw yields, respectively. The highest (13372 $\left.\mathrm{kg} \mathrm{ha}^{-1}\right)$, and the lowest (11166 kg ha-1 $)$ biological yields were obtained from the treatments of I4, and I1, respectively ( Table 3 ). The biological yield is eviedently affected by grain and straw yields.

Table 1: Mean squares and significant levels from analysis of variance on wheat production

\begin{tabular}{llrrrrl}
\hline \multirow{2}{*}{ Source } & Df & \multicolumn{3}{c}{ Mean squares } \\
\cline { 3 - 7 } & & \multicolumn{1}{c}{ GY } & \multicolumn{1}{c}{ BY } & \multicolumn{1}{c}{ SY } & HI & TGW \\
\hline Replication & 2 & 565146.01 & 4694852.23 & 2224427.10 & 12.96 & 5.790 \\
Treatments & 3 & $206769.62^{*}$ & $1519417.71^{\text {ns }}$ & $1001579.86^{\text {ns }}$ & $16.71^{\text {ns }}$ & $27.58^{*}$ \\
Error & 6 & 850395.73 & 2520147.27 & 971163.19 & 22.15 & 5.52 \\
Total & 11 & & & & & \\
\hline
\end{tabular}

$*$ and ns are significantly and insignificantly different at 5\% level of probability, respectively. Also, GY, BY, SY, HI and TGW are the grain, biological and straw yields, harvest index and 1000-grain weight, respectively.
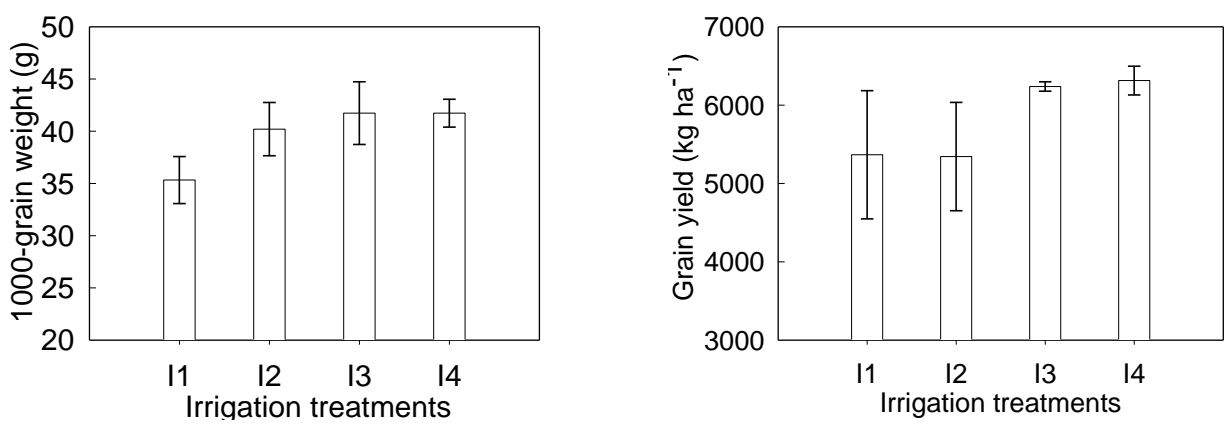

Figure. 1: The 1000-grain weight and grain yield of wheat from limited irrigation treatments

\subsection{Harvest Index}

In general $\mathrm{HI}$ is a function of grain yield and biological yield. In other words, HI is directly related to the grain yield and is inversely related to the biological yield. In this study, the effect of irrigation treatments on harvest index (HI) was insignificant and all HIs produced by the treatments were statistically identical (Table 1). The highest and lowest HI were 0.51 and 0.45 achieved from the treatments of I3, and I2, respectively ( Table 3). The HI values ranged in accordance with those reported by Musick and Porter (1990). 


\subsection{Applied Water-Yields Models}

The 1000-grain weight, grain, straw, and biological yields, and harvest index of wheat model as a function of applied water were acquired by regression analysis (Moghaddam, 1999) and results are presented in Table 2. It could be said that variation of wheat production can be explained by applied water by a polynomial (quadratic) function. The models shapes are in accordance with Hexem and Heady (1978). For grain, biological, and straw yields, harvest index, and 1000-grain weight of wheat, the combined observed and predicted values by acquired models are depicted in Fig. 2. There are well agreements between the measured and predicted values. These models can be applied to predict grain, straw, and biological yields of wheat by available water for irrigation. Based on the models, the highest grain yield $(6311 \mathrm{~kg}$ $\mathrm{ha}^{-1}$ ), biological yield (13194 $\left.\mathrm{kg} \mathrm{ha}^{-1}\right)$, straw yield $\left(6883 \mathrm{~kg} \mathrm{ha}^{-1}\right)$, TGW (43 g), and HI $(52 \%)$ were produced by applied water of $4257 \mathrm{~m}^{3} \mathrm{ha}^{-1}$ (Fig. 2).

Table 2: Applied water and grain, straw and biological yield; 1000-grain weight and harvest index models

\begin{tabular}{|c|c|c|c|c|c|}
\hline $\begin{array}{l}\mathrm{I1} \\
\mathrm{n}=3\end{array}$ & $\begin{array}{l}\mathrm{GY}=0.00096 \mathrm{~W}^{2} \\
\mathrm{R}^{2}=0.99\end{array}$ & $\begin{array}{l}\text { TGW }=0.0000063 \mathrm{~W}^{2} \\
\mathrm{R}^{2}=0.99\end{array}$ & $\begin{array}{l}\mathrm{BY}=0.0020 \mathrm{~W}^{2} \\
\mathrm{R}^{2}=0.97\end{array}$ & $\begin{array}{l}\mathrm{SY}=0.00104 \mathrm{~W}^{2} \\
\mathrm{R}^{2}=0.93\end{array}$ & $\begin{array}{l}\mathrm{HI}=0.000085 \mathrm{~W}^{2} \\
R^{2}=0.99\end{array}$ \\
\hline $\mathrm{I} 2$ & $\mathrm{GY}=0.00048 \mathrm{~W}^{2}$ & $\mathrm{TGW}=0.0000036 \mathrm{~W}^{2}$ & $\mathrm{BY}=0.0010 \mathrm{~W}^{2}$ & $\mathrm{SY}=0.00058 \mathrm{~W}^{2}$ & $\mathrm{HI}=0.000004 \mathrm{~W}^{2}$ \\
\hline$n=3$ & $\mathrm{R}^{2}=0.99$ & $\mathrm{R}^{2}=0.99$ & $\mathrm{R}^{2}=0.99$ & $\mathrm{R}^{2}=0.99$ & $\mathrm{R}^{2}=0.99$ \\
\hline 13 & $\mathrm{GY}=0.00028 \mathrm{~W}^{2}$ & $\mathrm{TGW}=0.0000019 \mathrm{~W}^{2}$ & $\mathrm{BY}=0.0006 \mathrm{~W}^{2}$ & $\mathrm{SY}=0.00027 \mathrm{~W}^{2}$ & $\mathrm{HI}=0.000002 \mathrm{~W}^{2}$ \\
\hline$n=3$ & $\mathrm{R}^{2}=0.97$ & $\mathrm{R}^{2}=0.97$ & $\mathrm{R}^{2}=0.94$ & $\mathrm{R}^{2}=0.91$ & $\mathrm{R}^{2}=0.98$ \\
\hline I4 & $\mathrm{GY}=0.00023 \mathrm{~W}^{2}$ & $\mathrm{TGW}=0.0000015 \mathrm{~W}^{2}$ & $\mathrm{BY}=0.0005 \mathrm{~W}^{2}$ & $\mathrm{SY}=0.00026 \mathrm{~W}^{2}$ & $\mathrm{HI}=0.000002 \mathrm{~W}^{2}$ \\
\hline$n=3$ & $\mathrm{R}^{2}=0.95$ & $\mathrm{R}^{2}=0.94$ & $\mathrm{R}^{2}=0.94$ & $\mathrm{R}^{2}=0.93$ & $\mathrm{R}^{2}=0.96$ \\
\hline All & $\mathrm{GY}=0.00029 \mathrm{~W}^{2}$ & TGW $=0.0197 \mathrm{~W}+0.000002 \mathrm{~W}^{2}$ & $\mathrm{BY}=6.0316 \mathrm{~W}+0.0007 \mathrm{~W}^{2}$ & $\mathrm{SY}=3.2965 \mathrm{~W}-0.0004 \mathrm{~W}^{2}$ & $\mathrm{HI}=0.0247 \mathrm{~W}-0.000003 \mathrm{~W}^{2}$ \\
\hline $\begin{array}{l}\text { treatments } \\
\mathrm{n}=12\end{array}$ & $\mathrm{R}^{2}=0.82$ & $\mathrm{R}^{2}=0.99$ & $\mathrm{R}^{2}=0.99$ & $\mathrm{R}^{2}=0.97$ & $\mathrm{R}^{2}=0.99$ \\
\hline
\end{tabular}

GY, W, TGW, BY, SY and HI are the grain yield, applied water, 1000-grain weight, biological yield, straw yield and harvest index, respectively.
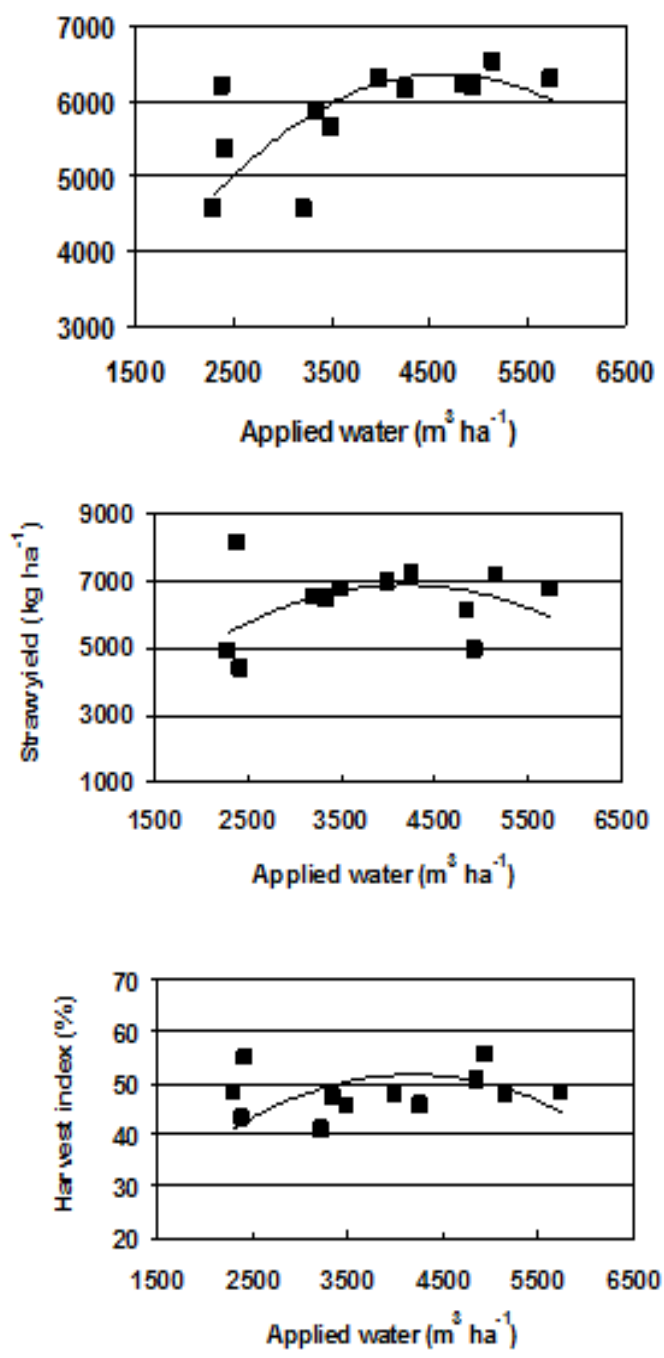
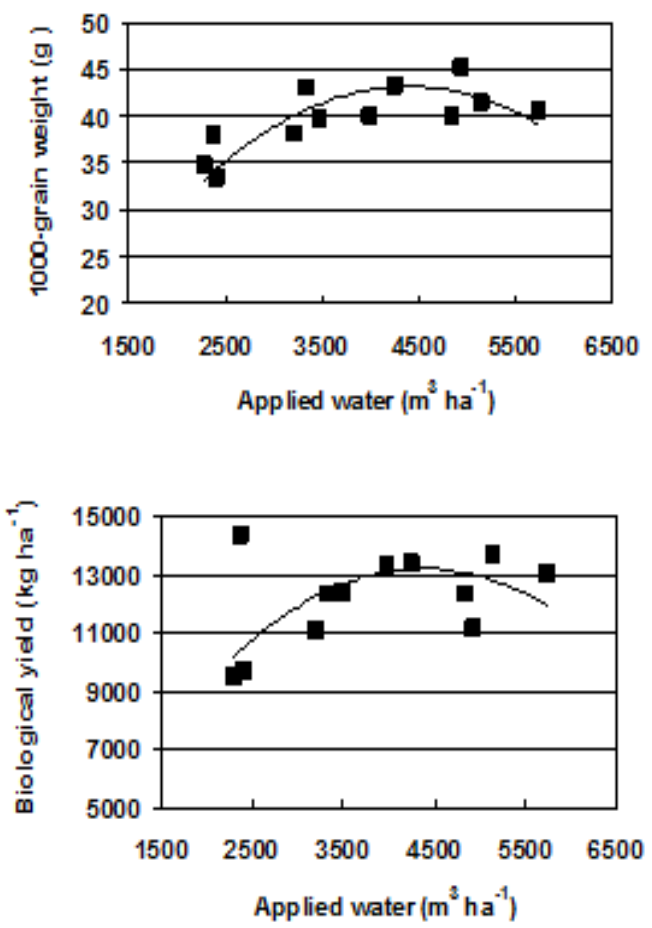

Figure 2: The grain, biological and straw yields, harvest index and 1000-grain weight of wheat from the combined observed and predicted values by models. 
Table 3: Average values ( \pm standard deviations) of grain, straw and biological yield; harvest index and 1000grain weight

\begin{tabular}{clllll}
\hline Treatments & \multicolumn{1}{c}{ Grain yield } & $\begin{array}{c}\text { Straw yield } \\
\left(\mathrm{kg} \mathrm{ha}^{-1}\right)\end{array}$ & Biological yield & $\begin{array}{c}\text { HI } \\
(\%)\end{array}$ & $\begin{array}{c}\text { TGW } \\
(\mathrm{g})\end{array}$ \\
\hline $\mathrm{I} 1$ & $5366 \pm 818$ & $5800 \pm 2031$ & $11166 \pm 2732$ & $49 \pm 6$ & $35 \pm 2$ \\
\hline $\mathrm{I} 2$ & $5343 \pm 692$ & $6575 \pm 152$ & $11918 \pm 748$ & $45 \pm 3$ & $40 \pm 3$ \\
\hline $\mathrm{I} 3$ & $6237 \pm 60$ & $6008 \pm 1005$ & $12246 \pm 1060$ & $51 \pm 4$ & $42 \pm 3$ \\
\hline $\mathrm{I} 4$ & $6313 \pm 184$ & $7058 \pm 270$ & $13372 \pm 327$ & $47 \pm 1$ & $42 \pm 1$ \\
\hline
\end{tabular}

\section{CONCLUSION}

The responses of winter wheat (cv. Tajan) productions to limited water condition under a semiarid environment were investigated. The results support the following conclusions:

Applying irrigation at cumulative Etc $=100,230$ and $350 \mathrm{~mm}$ (I3); and Etc $=100,230,350$ and 400 $\mathrm{mm}$ (I4) produced similar production. The highest grain, biological and straw yields were 6313, 13370 and $7058 \mathrm{~kg} \mathrm{ha}^{-1}$. To obtain optimum production for wheat cv. Tajan in Moghan, Iran climate condition, it is recommended to irrigate this crop at cumulative Etc $=100,230$ and $350 \mathrm{~mm}$. Acquired models in this study could be applied to predict grain, straw and biological yields as a function of applied water in a semi-arid environment. The economic analysis needs to evaluate experimental treatments.

\section{REFERENCES}

Abdmishani, S., Jafari Shabestari, J.1986. Effect of different irrigation regimes and seeding rate on yield of winter wheat. Iranian Journal of Agricultural Science, 17(4):4550.

Aggarwal, P. K., Singh, A. K., Chaturvedi, G. S., Sinha, S K.1986. Performance of wheat and triticale cultivars in a variable soil-water environment. Field Crops Res., 13:301- 315

Doorenbos , J., Kassam, A. H. 1979. Yield response to water, Irrigation and Drainage Paper 33. Food and Aricultural Organization of the United Nations. Rome, Italy

Doorenbos, J., Pruitt, W. O. 1977. Crop water requirements, Irrigation and Drainage Paper 24. Food and Aricultural Organization of the United Nations.Rome, Italy

Ehling, C. F., Le Mert, R. D.1976. Water use and productivity of wheat under five irrigation treatments. Soil Sci. Soc. Am. J., 40:750-755.

English, M., Nakamura, B. 1989. Effects of deficit irrigation and irrigation frequency on wheat yields. J. Irrig. Drain. Eng., 115:172-184.

Fallahi, H.A., Nasseri A., Siadat, A. 2008. Wheat yield components are positively influenced by nitrogen application under moisture deficit environments. Int. J. Agri. Biol., 10:673-6.

FAO.FAOSTAT.Agriculture.Rome,2008.Available in http://faostat. fao.org/ faostat/collections? subset=agriculture. Accessed at: December 2008

Fischer, R. A. 1970. The effects of water stress at various stages of development on yield processes in wheat.
Proc. symp. plant responses to climatic factors. Uppsala, Sweden. 15-20 Sept

Hexem, R. W., Heady, E. O. 1978. Water production function for irrigated agriculture. Center for Agricultural and Rural Development. Iowa State University Press, Ames, IA

Hoffman, G. L. , Howell T. A., Solomon, K. H.1992. Management of farm irrigation systems, Ameriacan Society of Agricultural Engineers, 2950 Niels Road. St Joseph, MI 49085-9659.

Hanks, R. J., 1974. Model for predicting plant yield as influenced by water use. Agron. J., 66: 660-665.

Hanks, R.J., Sorensen, R.B. 1984.Harvest index as influenced in spring wheat by water stress.p.205-209. in W. Day and R.K. Atkins (ed.) Wheat growth and modeling. NATO ASI series A: Life Science Vol. 86. Plenum Press, New York

Lal, R. B. 1985. Irrigation requirement of dwarf durum and aestivum wheat varieties. Indian J. Agron., 30: 207-213.

Mahmood , N., Akhtar B. Saleem, M. 2002. Scheduling irrigation in wheat grown at different seed rates. Asian Journal of Plant Sciences, 1(2): 136-139.

Moghaddam, M. 1999. Advnced engineering statistics. Faculty of Agriculture, Tabriz University (in Farsi). Iran

Musick, J. T., Porter, K.B. 1990. Wheat. In: Irrigation of Agricultural Crops, Editted by Stewart and Nielsen. 1990. pp :1217. American Society of Agronomy, Crop Science Society of America and Soil Science Society of America

Musick, J. T., Dusek D. A., Mathers, A. C. 1984. Irrigation water management of wheat. ASAE paper 84-2094. Am. Soc. Agric. Eng., St. Joseph, MI.

Nasseri, A. 1999. Analysis and optimization of water usecrop yield relation in Moghan plain, 9th Seminar of Iranian National Committee on Irrigation and Drianage: Allocation and Optimum Utilization Management of Water in Agriculture. Tehran. Iran. 271-288.

Nasseri, A., Fallahi, H. A. 2007.Water use efficiency of winter wheat under deficit iIrrigation. Journal of Biological Sciences, 7(1):19-26.

Nasseri, A. 2009. Precipitation variation in agricultural plain of Moghan, North-West Iran. J. Agric. Soc. Sci.,00:00000000

Oweis, T. 1997. Supplemental irrigation: a highly waterefficient practice. Pp:16, ICARDA. Aleppo. Syria

Passioura, J. B. 1977. Grain yield, harvest index and water use of wheat. J. Aust. Inst. Agric. Sci.,43:117-120

Rao, Y. G., Bhardwaj, R. B. L. 1981. Consumptive use of water, growth and yield of aestivum and durum wheat varieties at varying levels of nitrogen under limited and adequate irrigation situations. Indian $\mathrm{J}$. Agron. 26:243-250. 
Robinson, B., Freebarin, D. 2005. Water use efficiency of wheat. Available in www.apsru.gov.au

Shawcroft, R. W. 1983. Limited irrigation may drop yield, up profit. Colo. Rancher Farmer, 37(4): 35-38.
Zhang, J., Sui, X., Li, B., Su, B., Li J., Zhou, D. 1998. An improved water- use efficiency for winter wheat grown under reduced irrigation. Field Crops Res., 59: 91- 98 . 